\title{
Perencanaan Strategi Preventive Maintenance Pada Mesin Shot Blasting di PT. ABC dengan Klasifikasi ISMO
}

\author{
Herman Budi Harja ${ }^{1}$, Aditya Riyanto Putra ${ }^{2}$, Wibawa Kresnandi ${ }^{3}$ \\ $1,2,3$ Politeknik Manufaktur Bandung
}

Email: herman@polman-bandung.ac.id ${ }^{1}$, adityariyantoputra@gmail.com², wibawa@polmanbandung.ac.id ${ }^{3}$

\section{Informasi Artikel:}

Received:

21 September 2020

\section{Accepted :}

1 April 2021

Available :

30 April 2021

\begin{tabular}{l}
\hline Kata Kunci: \\
\hline Reliability; \\
Maintenance \\
strategy; \\
Downtime; \\
Complexity mark; \\
Availability;
\end{tabular}

ABSTRAK

Mesin shot blasting merupakan mesin pembersih produk hasil pengecoran dengan mekanisme shoting bola baja dari gaya sentrifugal yang dihasilkan putaran impeller/blast wheel. Sebagai mesin utama dalam proses akhir kegiatan produksi pengecoran, penurunan kehandalan mesin sangat berdampak negatif pada sistem produksi. Saat ini strategi perawatan peralatan produksi di PT ABC masih menerapkan corrective maintenance yang pelaksanaan perawatnnya tidak terencana dan bersifat reaktif saat kegagalan fungsi mesin terjadi. Hal ini mengakibatkan tingginya production loss dan biaya perawatan meningkat. Oleh karena itu strategi perawatan pada mesin shot blasting diubah menjadi jenis perawatan pencegahan (preventive maintenance). Kajian ini bertujuan untuk merencanakan sistem preventive maintenance (PM) mesin-mesin shot blasting PT. ABC berupa pembuatan jadwal PM, perhitungan waktu downtime dan kebutuhan teknisi pada setiap kegiatan PM_nya. Perencanaan sistem PM dicapai menggunakan metode ISMO (Inspection, Small repair, Medium repair dan Overhaul) dan dilakukan dalam beberapa tahapan yaitu identifikasi obyek mesin, membuat spesifikasi kerja PM, menentukan nilai kerumitan dan siklus pemeliharaan, perhitungan tenaga kerja dan waktu downtime mesin, membuat jadwal tahunan dan bulanan, serta beberapa dokumen perawatan lainnya. Mekanisme penentuan nilai kerumitan, ditentukan berdasarkan kemiripan spesifikasi mesin yang terdapat pada metodologi HP Garg. Perencanaan sistem PM mesin shot blasting telah berhasil dilakukan, beberapa informasi PM yang diperoleh yaitu (i)siklus perawatan mesin adalah $C-I_{1}-I_{2}-S_{1}-I_{3}-I_{4}-M_{1}-I_{5}-I_{6}-$ $\mathrm{S}_{2}-\mathrm{I}_{7}-\mathrm{I}_{8}-\mathrm{M}_{2}-\mathrm{I}_{9}-\mathrm{I}_{10}-\mathrm{S}_{3}-\mathrm{I}_{11}-\mathrm{I}_{12}-\mathrm{C}$, (ii) interval waktu antar kegiatan perawatan sebesar 1 bulan, (iii) waktu downtime kegiatan ISMO untuk mesin drum shot, batch shot dan hanger shot, (iv) jumlah dan level teknisi perawatan yang dibutuhkan pada setiap kegiatan ISMO untuk mesin drum shot, batch shot dan hanger shot. Verifikasi perhitungan nilai availability mesin shot blasting pada usulan jadwal PM diperoleh bahwa availability mesin meningkat menjadi lebih dari $80 \%$. 
strategy should be changed to a type of preventive maintenance. This study aims to plan preventive maintenance (PM) system for the shot blasting machines of PT. ABC, such as creating PM schedule, calculating machine downtime, and technician needs for each PM activity. PM system planning is achieved using the ISMO (Inspection, Small repair, Medium repair, and Overhaul) method. Its method was conducted in several stages, which start with identifying machine objects, making PM work specifications, determining the value of mark complexity and maintenance cycle, calculating machine downtime and technician needs. Then making schedules annual and monthly, and several other maintenance documents. The mechanism for determining the complexity value is determined based on the similarity of the HP Garg methodology's machine specifications. Finally, The planning of the shot blasting machine PM system has been successfully done, some of the PM information obtained are (i) the machine maintenance cycle is C - I1 - I2 - S1 - I3 - I4 - M1 - I5 - I6 - S2 I7 - I8 - M2 - I9 - I10 - S3 - I11 - I12 - C, (ii) the time interval between maintenance activities is one month, (iii) machine downtime for each shot blasting machine, (iV) the number and level of maintenance technicians required in every ISMO activity for drum shot, batch shot and hanger shot machines. The calculating verification of the shot blasting machine's availability value on the proposed PM schedule shows that machine availability increased to more than $80 \%$. 
Perencanaan Strategi Preventive Maintenance Pada Mesin Shot Blasting di PT. ABC dengan Klasifikasi ISMO

\section{PENDAHULUAN}

Proses Shot Blasting merupakan proses membersihkan benda kerja hasil cor dengan mekanisme shoting material abrasive (steel shot) dari gaya sentrifugal yang dihasilkan putaran impeller/blast whee/ putaran impeller [1]. Posisi mesin shot blasting pada proses produksi ialah mesin yang digunakan dalam tahap akhir proses produksi pengecoran. Sebagai mesin utama dalam proses akhir kegiatan produksi pengecoran, penurunan kehandalan mesin sangat berdampak negatif pada perusahaan, seperti berhentinya proses produksi, menurunnya kualitas produk dan delivery terlambat. Menurut Antony Corder dan K. Hadi pada umumnya sebuah produk baik yang berupa komponen ataupun mesin produksi akan mengalami kerusakan atau kegagalan fungsi, tetapi waktu pakainya dapat diperpanjang melalui upaya kegiatan perawatan [2]. Perawatan merupakan segala upaya teknis maupun administratif untuk memelihara dan menjaga serta memperbaiki obyek mesin/ sistem/fasilitas, dengan melakukan adjustment ataupun penggantian yang diperlukan sehingga diperoleh kondisi mesin sesuai standar dalam fungsi dan kualitasnya [3; 4; 5].

Saat ini, PT ABC belum memiliki sistem pemeliharaan terjadwal, dan masih menerapkan strategi perawatan reaktif atau corrective maintenance, dimana kegiatan perawatannya hanya dilakukan setelah terjadi kegagalan fungsi pada mesin [6]. Pada Gambar 1 ditunjukkan grafik frekuensi terjadinya kerusakan mesin shot blasting selama bulan Agustus 2019 hingga Januari 2020, dokumen rekap perawatan mesin shot blasting perusahaan menunjukkan bahwa mesin sering mengalami trouble repair dengan durasi waktu perbaikan (time to repair) yang lama karena faktor ketidaksiapan sumber daya perawatan (sparepart, teknisi, peralatan perawatan). Strategi perawatan reaktif mengakibatkan rendahnya availability mesin, tingginya production lost, dan biaya perawatan yang tinggi.

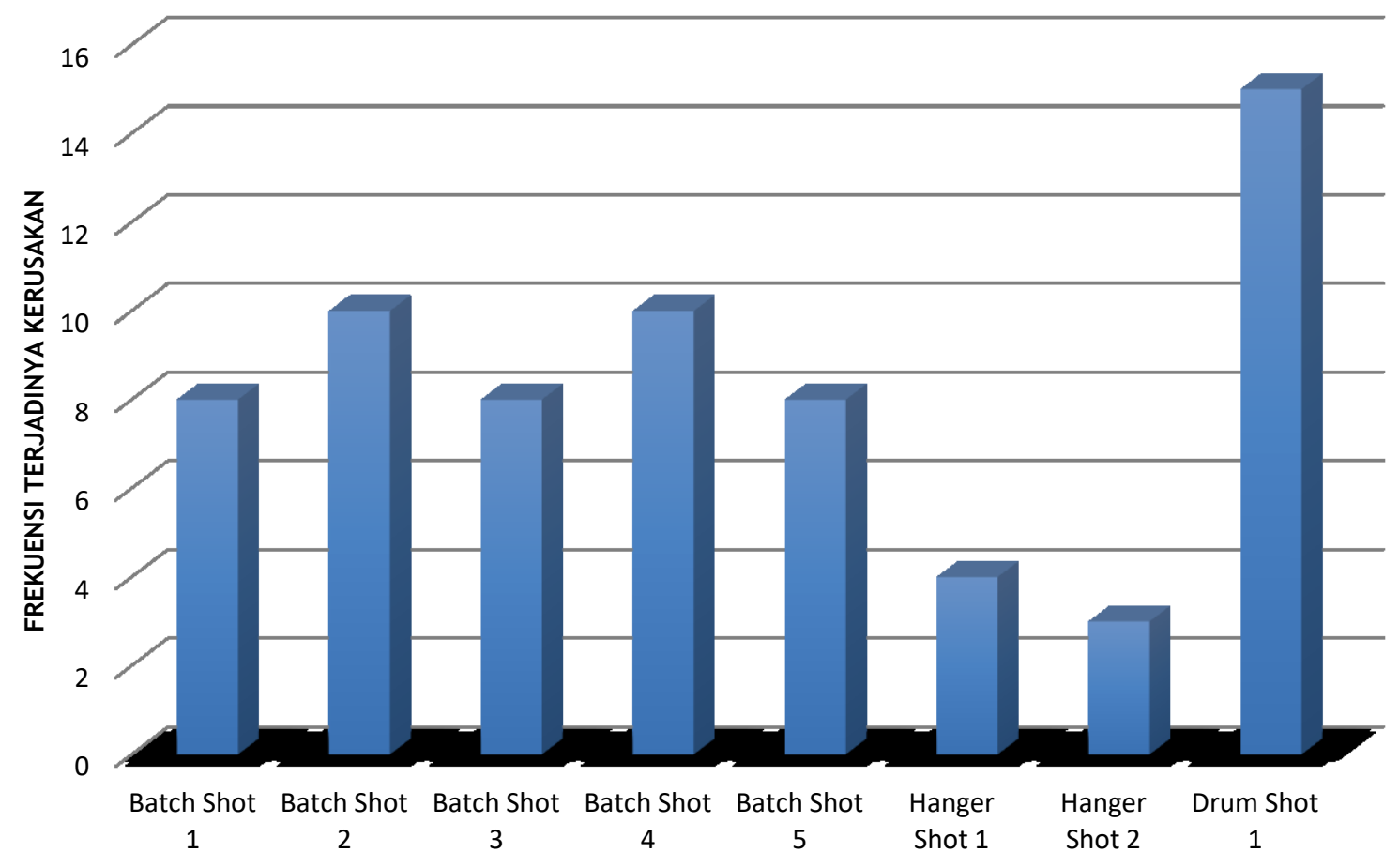

Gambar 1. Grafik frekuensi terjadinya kerusakan mesin shot blasting selama bulan Agustus 2019 hingga Januari 2020 
Dalam rangka perbaikan kinerja sitem perawatan terhadap peralatan perusahaan, terutama untuk peningkatan availability dan performance mesin, serta untuk meminimalkan kekerapan terjadinya trouble repair, maka pada kajian ini diusulkan penerapan strategi perawatan pencegahan (PM) untuk mesin Shot Blasting. Metoda PM yang digunakan adalah dengan metode ISMO (Inspection, Small repair, Medium repair dan Overhaul). Kegiatan perawatan dilaksanakan secara terencana/terjadwal berbasis asumsi beban operasi penggunaan mesin, Interval atau selang kegiatan antar kegiatan PM dan lingkup daftar aktivitas setiap kegiatan PM ditentukan berdasarkan rekomendasi pabrik pembuat mesin ataupun berbasis nilai kerumitan pada mesin produksi. Nilai kerumitan mesin dihitung berdasarkan (i) spesifikasi mesin dan (ii) beban yang diterima mesin seperti jenis material yang diproses dan durasi waktu utilisasi [7].

Beberapa penelitian pada topik perawatan PM telah dilakukan sebelumnya. Bahtiar (2009) melakukan kajian penjadwalan preventive maintenance mesin $B$. Flute dengan metode age replacement [8]. Kajian perancangan preventive maintenance berdasarkan metoda Reliability Centered Maintenance (RCM) pada peralatan di PT Sinar Sosro telah dilakukan oleh Yansen (2011) [9]. Paulus (2013) melakukan kajian perawatan mesin jenis strategi preventive maintenance dengan modularity design [10]. Patardo (2016) membuat perencanaan sistem perawatan alat angkat kapasitas 5 ton menggunakan metoda preventive maintenance khususnya dengan perhitungan OEE (Overall Equipment Effectiveness) [11]. Herman (2019) mengidentifikasi kegagalan komponen-komponen mesin curing menggunakan metoda distribusi Weibull untuk merekomendasikan evaluasi nilai interval jadwal preventive maintenance [12].

Penelitian perawatan terhadap obyek mesin shot blasting juga telah dilakukan sebelumnya oleh beberapa peneliti, diantaranya Riezna (2018) melakukan analisa proporsi kondisi mesin dan keandalan mesin hanger shot blast menggunakan metode Markov [13], Rinaldi (2019) melakukan kajian evaluasi penjadwalan perawatan mesin hanger shot blast kazo dengan RCM II Dan MVSM [14].

Berdasarkan paparan di atas, penelitian perawatan jenis strategi perawatan pencegahan (PM) dapat dilakukan dengan berbagai metoda dan dapat diterapkan untuk berbagai obyek peralatan produksi. Selain itu penelitian perawatan dengan obyek mesin shot blasting juga dapat dikaji menggunakan berbagai metoda. Kajian perawatan yang dilakukan pada paper ini bertujuan membuat dokumen perawatan pencegahan (PM) berupa jadwal PM pada mesin Shot Blasting, spesifikasi kegiatan perawatan dan perhitungan kebutuhan jumlah dan level teknisi serta penentuan waktu downtime. Metoda penentuan nilai kerumitan sebuah mesin diperoleh berdasarkan spesifikasi yang terdapat pada tabulasi HP Garg. Dikarenakan tidak terdapatnya spesifikasi yang sesuai pada tabulasi HP Garg untuk tiga objek mesin shot blasting yang dikaji dalam penelitian ini, maka pendefinisian nilai kerumitan diperoleh berdasarkan beban produksi pada mesin dan kemiripan dengan spesifikasi yang ada dalam tabulasi HP. Garg.

\section{METODOLOGI PENELITIAN}

Beberapa tahapan yang dilakukan pada penelitian ini diantaranya yaitu diawali dengan mengidentifikasi mesin, kemudian membuat spesifikasi kerja dengan klasifikasi ISMO, menentukan nilai kerumitan dan siklus pemeliharaan, menghitung tenaga kerja dan waktu 
Perencanaan Strategi Preventive Maintenance Pada Mesin Shot Blasting di PT. ABC dengan Klasifikasi ISMO

downtime mesin untuk kegiatan PM, verifikasi simulasi perhitungan availability mesin shot blasting, dan berikutnya merekomendasikan usulan penerapan PM.

\subsection{Identifikasi Mesin Shot Blasting}

Identifikasi mesin dilakukan untuk mengamati detail spesifikasi fungsi komponen-komponen mesin shot blasting. Identifikasi ini dilakukan dengan cara mengamati mesin secara langsung maupun membaca manual book. Dari pengamatan tersebut dapat diketahui bagian mana saja dari komponen mesin tersebut yang perlu dilakukan pengecekan.

\subsection{Membuat Spesifikasi Kerja Kegiatan Preventive Maintenance}

Spesifikasi kerja setiap jenis kegiatan PM dibuat sebagai pedoman dalam pelaksanaan kegiatan preventive maintenance. Spesifikasi kerja berisi detail item tahapan kegiatan pemeriksaan dan perbaikna komponen-komponen mesin shot blasting. Jenis kegiatan PM tersebut diklasifikasikan menjadi empat kategori yaitu inspeksi (inspection), reparasi kecil (small repair), reparasi sedang (medium repair), dan bongkar total (overhaul).

\subsection{Menentukan Nilai Kerumitan dan Siklus Pemeliharaan}

Nilai kerumitan merupakan indeks relative dari kerumitan sebuah mesin yang berperan penting dalam menentukan durasi perbaikan, siklus pemeliharaan, dan perencanaan tenaga kerja. Nilai kerumitan mesin shot blasting ditentukan melalui kemiripan dengan spesifikasi yang ada dalam tabulasi HP. Garg. Setelah didapat nilai kerumitan, maka perlu memperhatikan lama waktu penggunaan mesin, tipe produksi yang digunakan serta spesifikasi mesin untuk menentukan siklus pemeliharaan mana yang sesuai untuk mesin shot blasting.

\subsection{Menghitung Tenaga Kerja dan Waktu Downtime}

Waktu downtime mesin untuk setiap kegiatan ISMO dihitung berdasarkan nilai kerumitan mesin shot blasting dikali dengan nilai pengali ISMO untuk pemberhentian mesin [3].

Waktu downtime Mesin $=$ Nilai Kerumitan Mesin $\times$ Nilai Pengali ISMO

Tenaga kerja yang dibutuhkan untuk setiap kegiatan ISMO dihitung berdasarkan nilai kerumitan mesin shot blasting dikali nilai pengali ISMO untuk jam kerja teknisi kemudian dibagi dengan waktu downtime mesin yang dikali dengan jam kerja 1 shift [3].

Tenaga Kerja $=\frac{\text { Nilai Kerumitan Mesin } x \text { Nilai Pengali ISMO }}{\text { Waktu Pemberhentian Mesin } x \text { Jam Kerja } 1 \text { Shift }}$

\subsection{Menghitung Availability}

Availability merupakan rasio dari lama waktu suatu mesin pada suatu pabrik digunakan terhadap waktu yang ingin digunakan (waktu tersedia). Availability merupakan ukuran sejauh mana mesin tersebut bisa berfungsi. Availability ratio adalah tingkat efektivitas beroperasinya suatu mesin/peralatan. Nilai availability yaitu dengan cara menghitung selisih loading time dan waktu downtime mesin dengan total waktu yang tersedia [15].

$$
\text { Availability }=\frac{\text { Total time availbale }- \text { Downtime }}{\text { Total time availbale }} \times 100
$$




\section{HASIL}

Sesuai dengan fokus kajian penelitian, pembuatan perencanaan kegiatan preventive maintenance mesin shot blasting dengan metoda ISMO adalah untuk mendapatkan nilai kerumitan yang digunakan dalam menentukan siklus pemeliharaan, jumlah dan level tenaga kerja, dan waktu downtime mesin, serta memverifikasi usulan jadwal PM dengan menghitung availability mesin shot blasting pada kegiatan corrective maintenance dan preventive maintenance.

\subsection{Nilai kerumitan, Siklus Pemeliharaan, Tenaga Kerja, dan Waktu Pemberhentian Mesin Untuk Kegiatan PM}

\subsubsection{Nilai Kerumitan}

Nilai kerumitan mesin shot blasting yaitu drum shot, batch shot, dan hanger shot ditentukan melalui kemiripan spesifikasi dengan Tabel yang ada pada buku HP. Garg seperti yang ditampilkan pada Gambar 2. Untuk drum shot, menghitung volume kerucut dari drum dan didapatkan volume $0,942 \mathrm{~m}^{2}$. Hasil volume tersebut, mendekati dengan volume kerucut yang dihitung pada salah satu spesifikasi dalam tabulasi HP. Garg yaitu cleaning drums ukuran $2400 \mathrm{~L}$ x 1200D yang volume kerucutnya 0,9043 $\mathrm{m}^{2}$. Kemudian batch shot dan hanger shot, ditentukan melalui posisi benda kerja selama proses shot berlangsung. Posisi benda kerja batch shot berada pada karet barel yang terus berputar juga hanger shot yang digantungkan pada hanger yang terus berputar. Hal tersebut memiliki kemiripan dengan spesifikasi continuous belt type with 2 nozzles dan continuous rotary table with 2 nozzles.

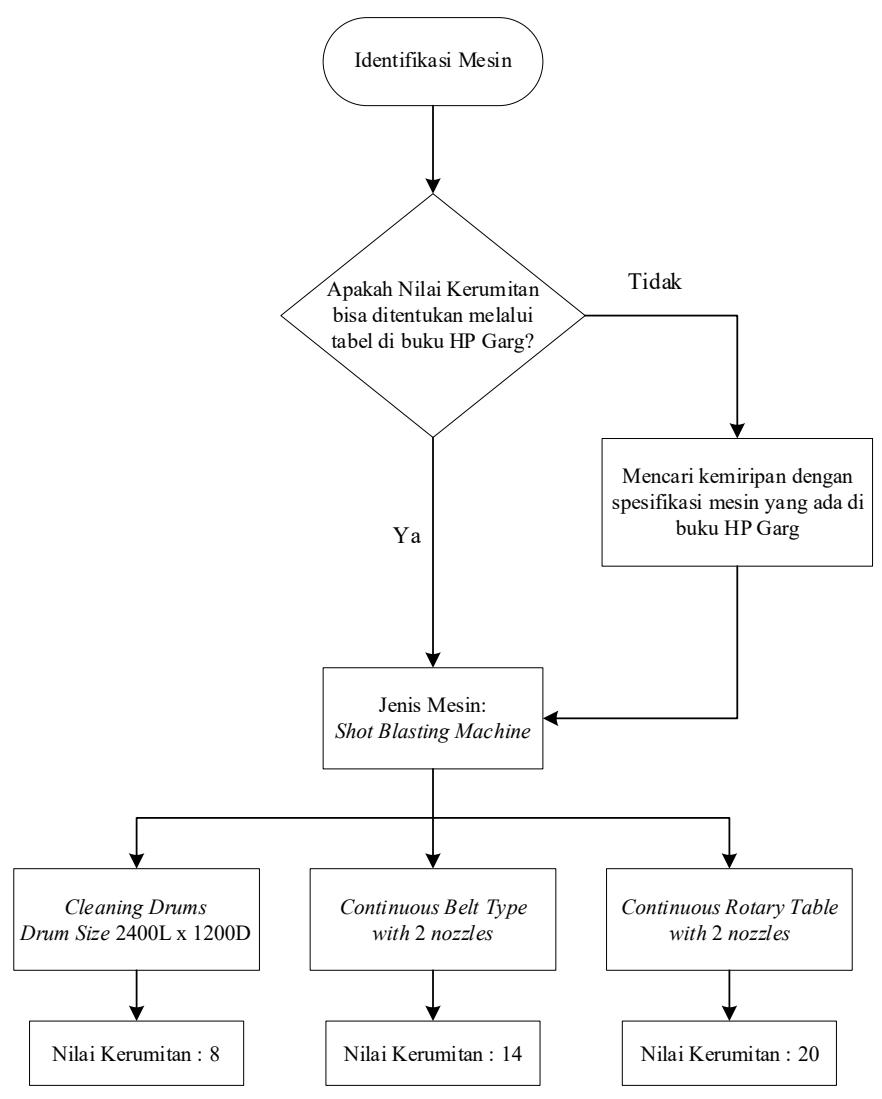

Gambar 2. Diagram alir penentuan nilai kerumitan mesin shot blasting 
Perencanaan Strategi Preventive Maintenance Pada Mesin Shot Blasting di PT. ABC dengan Klasifikasi ISMO

Pada Tabel 1. ditampilan Nilai kerumitan mesin Shot Blasting yang diperoleh dari tahapan penentuan nilai kerumitan mesin.

Tabel 1. Nilai kerumitan mesin shot blasting

\begin{tabular}{c|c|c|c}
\hline Nama Mesin & Type/Description & Spesification & $\begin{array}{c}\text { Repair } \\
\text { Complexity }\end{array}$ \\
\hline Mesin Drum Shot & Cleaning drums & $2400 \mathrm{~L} \times 1200 \mathrm{D}$ & 8 \\
\hline Mesin Batch Shot & Shot Blasting & $\begin{array}{c}\text { Continuous belt type } \\
\text { with 2 nozzles }\end{array}$ & 14 \\
\cline { 1 - 3 } $\begin{array}{c}\text { Mesin Hanger } \\
\text { Shot }\end{array}$ & Chambers & $\begin{array}{c}\text { Continuous rotary table with 2 } \\
\text { nozzles }\end{array}$ & 20 \\
\hline
\end{tabular}

\subsubsection{Siklus Pemeliharaan}

Waktu penggunaan mesin shot blasting pada proses produksi di PT. ABC adalah 24 jam sehari dengan 3 shift kerja yang rata-rata 8 jam / 1 shift kerja. Tipe produksi produk adalah bersifat massal. Berdasarkan nilai kerumitan mesin, shift kerja penggunaan mesin, dan tipe produksi yang diberikan pada mesin telah diketahui, maka siklus pemeliharaan dan interval wakttu antar kegiatan PM untuk mesin shot blasting dapat diperoleh. Siklus pemeliharaan mesin yaitu $C-I_{1}-I_{2}-S_{1}-I_{3}-I_{4}-M_{1}-I_{5}-I_{6}-S_{2}-I_{7}-I_{8}-M_{2}-I_{9}-I_{10}-S_{3}-I_{11}-I_{12}$

- C dan interval waktu sebesar 1 bulan seperti yang ditunjukkan pada Tabel 2.

Tabel 2. Siklus pemeliharaan mesin shot blasting

\begin{tabular}{c|c|c|c|c|c|c}
\hline \multirow{2}{*}{ Equipment } & \multicolumn{4}{|c|}{ Repair Cycle } & t (Bulan) & T (Tahun) \\
\cline { 2 - 6 } & Siklus & $\mathbf{M}$ & $\mathbf{S}$ & $\mathbf{I}$ & $\begin{array}{c}\text { Working } \\
\text { Shift 3 }\end{array}$ & $\begin{array}{c}\text { Working } \\
\text { Shift 3 }\end{array}$ \\
\hline $\begin{array}{c}\text { Shot Blasting } \\
\text { Chambers }\end{array}$ & $\begin{array}{c}\mathbf{C}-\mathbf{I}_{\mathbf{1}}-\mathbf{I}_{\mathbf{2}}-\mathbf{S}_{\mathbf{1}}-\mathbf{I}_{\mathbf{3}}-\mathbf{I}_{\mathbf{4}}-\mathbf{M}_{\mathbf{1}}-\mathbf{I}_{\mathbf{5}}-\mathbf{I}_{\mathbf{6}} \\
-\mathbf{S}_{\mathbf{2}}-\mathbf{I}_{\mathbf{7}}-\mathbf{I}_{\mathbf{8}}-\mathbf{M}_{\mathbf{2}}-\mathbf{I}_{\mathbf{9}}-\mathbf{I}_{\mathbf{1 0}}-\mathbf{S}_{\mathbf{3}}-\mathbf{I}_{\mathbf{1 1}} \\
-\mathbf{I}_{\mathbf{1 2}}-\mathbf{C}\end{array}$ & 2 & 3 & 13 & 1 & 1 \\
\hline
\end{tabular}

\subsubsection{Waktu Downtime Mesin}

Waktu downtime mesin dihitung sebagai acuan nilai durasi waktu pelaksanaan setiap kegiatan ISMO preventive maintenance. Berikut contoh perhitungan waktu downtime mesin untuk kegiatan inspeksi pada mesin drum shot dengan menggunakan Persamaan (1).

$$
\text { WP } \quad \begin{aligned}
& =\mathrm{Nk} \times \mathrm{n} \\
& =8 \times 0,15 \\
& =1,2 \text { hari }
\end{aligned}
$$

Jadi, waktu pemberhentian mesin drum shot untuk kegiatan inspeksi adalah 1,2 hari.

Waktu downtime kegiatan perawatan inspection, small repair, medium repair, dan overhaul untuk mesin drum shot, batch shot, dan hanger shot ditunjukkan pada Tabel 3. 
Herman Budi Harja, Aditya Riyanto Putra, Wibawa Kresnandi

Tabel 3. Waktu downtime mesin drum shot, batch shot, dan hanger shot

\begin{tabular}{c|c|c|c|c}
\hline $\begin{array}{c}\text { Jenis } \\
\text { Mesin }\end{array}$ & $\begin{array}{c}\text { Nilai } \\
\text { Kerumitan }\end{array}$ & $\begin{array}{c}\text { Kegiatan } \\
\text { Pemeliharaan }\end{array}$ & $\begin{array}{c}\text { Nilai Pengali } \\
\text { ISMO (hari) }\end{array}$ & $\begin{array}{c}\text { Waktu Pemberhentian } \\
\text { Mesin }\end{array}$ \\
\hline \multirow{4}{*}{$\begin{array}{c}\text { Drum } \\
\text { Shot }\end{array}$} & \multirow{3}{*}{8} & Inspection & 0,15 & 1,2 hari \\
\cline { 3 - 5 } & & Small Repair & 0,25 & 2 hari \\
\cline { 3 - 5 } & & Medium Repair & 0,6 & 4,8 hari \\
\cline { 3 - 5 } & & Overhaul & 1 & 8 hari \\
\hline \multirow{3}{*}{$\begin{array}{c}\text { Batch } \\
\text { Shot }\end{array}$} & \multirow{3}{*}{14} & Inspection & 0,15 & 2,1 Hari \\
\cline { 3 - 5 } & & Small Repair & 0,25 & 3,5 Hari \\
\cline { 3 - 5 } & & Medium Repair & 0,6 & 8,4 Hari \\
\cline { 3 - 5 } & & Overhaul & 1 & 14 Hari \\
\hline \multirow{3}{*}{$\begin{array}{c}\text { Shot } \\
\text { Shot }\end{array}$} & \multirow{3}{*}{20} & Inspection & 0,15 & 3 Hari \\
\cline { 3 - 5 } & & Small Repair & 0,25 & 5 Hari \\
\cline { 3 - 5 } & & Medium Repair & 0,6 & 12 Hari \\
\cline { 3 - 5 } & & Overhaul & 1 & 20 Hari \\
\hline
\end{tabular}

\subsubsection{Tenaga Kerja}

Jumlah tenaga kerja dihitung untuk digunakan sebagai acuan jumlah teknisi maupun helper yang dibutuhkan pada setiap pelaksanaan kegiatan ISMO preventive maintenance. Berikut salah satu contoh perhitungan jumlah tenaga kerja yang dibutuhkan untuk kegiatan inspeksi pada mesin drum shot dengan menggunakan Persamaan (2).
Untuk kegiatan Inspeksi / Inspection
$\mathrm{NK}=8 \quad \mathrm{MH}=8 \times 1=8$
$\mathrm{WP}=1,2$ hari $\quad \mathrm{JK}=8$ jam per hari

Sehingga dapat ditentukan jumlah tenaga kerja untuk melakukan kegiatan inspeksi:

$(\mathrm{TK})={ }^{\mathrm{MH}} / \mathrm{WP} \times \mathrm{JK}$

$(\mathrm{TK})={ }^{8} I_{1,2 \times 8}=0,83 \approx$ pembulatan 1 orang (teknisi).

Pada Tabel 4. Ditampilkan jumlah tenaga kerja yang dibutuhkan untuk kegiatan PM pada mesin drum shot, batch shot, dan hanger shot.

Tabel 4. Kebutuhan Jumlah tenaga kerja untuk kegiatan PM pada mesin drum shot, batch shot, dan hanger shot

\begin{tabular}{c|c|c|c|c}
\hline $\begin{array}{c}\text { Jenis } \\
\text { Mesin }\end{array}$ & $\begin{array}{c}\text { Nilai } \\
\text { Kerumitan }\end{array}$ & $\begin{array}{c}\text { Kegiatan } \\
\text { Pemeliharaan }\end{array}$ & $\begin{array}{c}\text { Nilai Pengali } \\
\text { ISMO }\end{array}$ & $\begin{array}{c}\text { Waktu Pemberhentian } \\
\text { Mesin }\end{array}$ \\
\hline \multirow{2}{*}{ Drum Shot } & \multirow{2}{*}{8} & Inspection & 1 & 1 orang (teknisi) \\
\cline { 3 - 5 } & & Small Repair & 5 & $\begin{array}{c}3 \text { orang (2 teknisi + 1 } \\
\text { helper) }\end{array}$ \\
\cline { 3 - 5 } & & Medium Repair & 18 & $\begin{array}{c}4 \text { orang (3 teknisi + 1 } \\
\text { helper) }\end{array}$ \\
\hline
\end{tabular}

8 | JTRM 
Perencanaan Strategi Preventive Maintenance Pada Mesin Shot Blasting di PT. ABC dengan Klasifikasi ISMO

\begin{tabular}{|c|c|c|c|c|}
\hline $\begin{array}{l}\text { Jenis } \\
\text { Mesin }\end{array}$ & $\begin{array}{c}\text { Nilai } \\
\text { Kerumitan }\end{array}$ & $\begin{array}{c}\text { Kegiatan } \\
\text { Pemeliharaan }\end{array}$ & $\begin{array}{l}\text { Nilai Pengali } \\
\text { ISMO }\end{array}$ & $\begin{array}{c}\text { Waktu Pemberhentian } \\
\text { Mesin }\end{array}$ \\
\hline & & Overhaul & 30 & $\begin{array}{c}4 \text { orang (3 teknisi + } 1 \\
\text { helper) }\end{array}$ \\
\hline \multirow{4}{*}{ Batch Shot } & \multirow{4}{*}{14} & Inspection & 1 & 1 orang (teknisi) \\
\hline & & Small Repair & 5 & $\begin{array}{c}3 \text { orang (2 teknisi }+1 \\
\text { helper) }\end{array}$ \\
\hline & & Medium Repair & 18 & $\begin{array}{c}4 \text { orang (3 teknisi }+1 \\
\text { helper) }\end{array}$ \\
\hline & & Overhaul & 30 & $\begin{array}{c}4 \text { orang (3 teknisi }+1 \\
\text { helper) }\end{array}$ \\
\hline \multirow{4}{*}{$\begin{array}{l}\text { Hanger } \\
\text { Shot }\end{array}$} & \multirow{4}{*}{20} & Inspection & 1 & 1 orang (teknisi) \\
\hline & & Small Repair & 5 & $\begin{array}{c}3 \text { orang (2 teknisi }+1 \\
\text { helper) }\end{array}$ \\
\hline & & Medium Repair & 18 & $\begin{array}{c}4 \text { orang (3 teknisi }+1 \\
\text { helper) }\end{array}$ \\
\hline & & Overhaul & 30 & $\begin{array}{c}4 \text { orang (3 teknisi + } 1 \\
\text { helper) }\end{array}$ \\
\hline
\end{tabular}

\subsection{Perhitungan Availability}

Verifikasi perhitungan availability dilakukan untuk mengetahui perbandingan ketersediaan mesin antara penerapan strategi perawatan jenis corrective maintenance dengan usulan jadwal preventive maintenance dalam 1 tahun. Berikut contoh perhitungan availability pada mesin drum shot dengan menggunakan Persamaan (3). Mesin digunakan dalam 3 shift dengan 5760 jam kerja.

Data rekap perawatan corrective maintenance selama 1 tahun, mesin drum Shot secara mengalami kerusakan sebanyak 30 kali dengan waktu perbaikan 3 hari, artinya total waktu breakdown adalah sebesar 2160 jam. Sehingga nilai availability mesin drum shot adalah sebesar $62.5 \%$.

$$
\text { Availability }=\frac{5760-2160}{5760} \times 100=62,5 \%
$$

Jadwal perawatan PM yang diusulkan untuk mesin drum Shot adalah kegiatan inspeksi 6 kali dengan waktu downtime 1,2 hari, small repair 1 kali dengan waktu downtime 2 hari, medium repair 1 kali dengan waktu downtime 4,8 hari, sehingga didapat total waktu downtime kegiatan preventive maintenance sebesar 336 jam. Sehingga nilai availability mesin drum shot sebesar $94,17 \%$.

$$
\text { Availability }=\frac{5760-336}{5760} \times 100=94,17 \%
$$

Pada Tabel 5. Ditampilkan Tabel presentasi nilai availability obyek kajian mesin-mesin shot blasting untuk strategi corrective maintenance dan preventive maintenance. Verifikasi perhitungan terhadap nilai availability setiap mesin shot blasting menunjukkan bahwa usulan penerapan PM pada mesin shot blasting yang telah dibuat dapat meningkatkan nilai availability mesin. 
Herman Budi Harja, Aditya Riyanto Putra, Wibawa Kresnandi

Tabel 5 Persentase nilai Availability mesin shot blasting untuk strategi corrective maintenance dan preventive maintenance

\begin{tabular}{c|c|c}
\hline \multirow{2}{*}{ Mesin } & \multicolumn{2}{c}{ Corrective Maintenance } \\
\cline { 2 - 3 } & $62,5 \%$ & Preventive Maintenance \\
\hline Drum Shot & $80 \%$ & $94,17 \%$ \\
\hline Batch Shot 1 & $75 \%$ & $83,08 \%$ \\
\hline Batch Shot 2 & $80 \%$ & $83,08 \%$ \\
\hline Batch Shot 3 & $75 \%$ & $83,08 \%$ \\
\hline Batch Shot 4 & $80 \%$ & $83,08 \%$ \\
\hline Batch Shot 5 & $80 \%$ & $86,58 \%$ \\
\hline Hanger Shot 1 & $82,5 \%$ & $82,08 \%$ \\
\hline Hanger Shot 2 & & $83,33 \%$ \\
\hline
\end{tabular}

\section{KESIMPULAN}

Perencanaan penerapan startegi perawatan pencegahan atau preventive maintenance untuk obyek kajian mesin shot blasting telah berhasil dilakukan dan menghasilkan beberapa rekomendasi pedoman pelaksanaan perawatan pencegahan seperti siklus perawatan dan durasi interval waktu antar kegiatan PM, waktu downtime setiap kegiatan PM, dan jumlah dan level tenaga kerja setiap kegiatan PM. Siklus pemeliharaan mesin shot blasting yang diperoleh adalah $\mathbf{C}-\mathbf{I}_{1}-\mathbf{I}_{2}-\mathbf{S}_{1}-\mathbf{I}_{3}-\mathbf{I}_{4}-\mathbf{M}_{\mathbf{1}}-\mathbf{I}_{5}-\mathbf{I}_{6}-\mathbf{S}_{2}-\mathbf{I}_{\mathbf{7}}-\mathbf{I}_{8}-\mathbf{M}_{2}-\mathbf{I}_{\mathbf{9}}-\mathbf{I}_{10}-\mathbf{S}_{\mathbf{3}}-\mathbf{I}_{11}$ - $\mathbf{I}_{\mathbf{1 2}}$ - C, dan jarak interval untuk tiap kegiatan pemeliharaan adalah 1 bulan. Waktu downtime untuk setiap kegiatan PM inspection, small Repair, medium Repair, dan overhaul pada mesin drum shot secara berurutan adalah sebesar 1,2 hari; 2 hari; 4,8 hari; dan 8 hari, pada mesin batch shot ialah sebesar 2,1 hari; 3,5 hari; 8,4 hari, dan 14 hari, dan pada mesin hanger shot yaitu sebesar 3 hari; 5 hari; 12 hari; dan 20 hari. Jumlah tenaga kerja yang dibutuhkan setiap kegiatan $P M$ pada mesin shot blasting yaitu inspection 1 orang, small Repair 3 orang (2 teknisi +1 helper), medium Repair 4 orang ( 3 teknisi +1 helper), dan overhaul 4 orang (3 teknisi +1 helper). Verifikasi perhitungan nilai availability mesin shot blasting pada usulan jadwal PM diperoleh bahwa availability mesin meningkat menjadi lebih dari $80 \%$.

\section{REFERENSI}

[1] https://cvsentrateknik.wordpress.com/2016/03/03/apa-itu-shotblast/

[2] Corder,dkk, Teknik Manajemen Pemeliharaan, Jakarta; Erlangga, 1996.

[3] Sehwarat, dkk, Production Management, Jakarta; Erlangga, 2001.

[4] O'Connor, dkk, Practical Reliability Engineering, England; Jonh Wiley \& Sons Ltd. 2001.

[5] I. T. U. ITU, Definition of terms related to quality of service, vol. 55, no. 9, 2008.

[6] Heizer, J. dan Render, B., Operation Management, New Jersey, USA; 8 Edition, Prentice Hall, Inc. Upper Saddle River, 2001.

[7] H.P. Garg, Industrial Maintenance, New Delhi, India; S. Chand \& Company LTD, 2002.

[8] Bahtiar, S. dkk, "Penjadwalan Preventive Maintenance Mesin B.Flute Pada PT AMW", Jurusan Teknik Industri, Universitas Bina Nusantara, 2009.

[9] Siswanto, Y., "Perancangan Preventive Maintenance Berdasarkan Metoda Reliability Centered Maintenance (RCM) pada PT. Sinar Sosro", Skripsi, Departemen Teknik 
Industri, Universitas Sumatera Utara, 2011.

[10] Paulus Tarigan, dkk, "Perawatan Mesin Secara Preventive Maintenance dengan Modularity Design Pada PT. RXZ", Jurusan Teknik Industri, Universitas Sumatera Utara, 2013.

[11] Patardo S., dkk, "Perencanaan Sistem Perawatan Alat Angkat Kapasitas 5 Ton Dengan Metode Preventive Maintenance", Jurnal, Program Studi Teknik Industri, Universitas Riau Kepulauan, 2016.

[12] Herman B., "Usulan Pembaharuan Jadwal Preventive Maintenance pada Mesin Curing PCR di PT. XYZ MEnggunakan Metoda Distribusi Weibull", Jurnal Teknologi dan Rekayasa MAnufaktur, Politeknik Manufaktur Bandung, Vol.1 (1), 2019.

[13] Riezna W., "Analisis Proporsi Kondisi Mesin dan Keandalan Pada Mesin Hanger Shot Blast Dengan Menggunakan Metode MarkoV', Jurnal MATRIX, Jurusan Teknik Industri, Universitas Muhammadiyah Gresik, 2018.

[14] Rinaldi S., dkk, "Evaluasi Penjadwalan Perawatan Mesin Hanger Shot Blast Kazo Dengan RCM II", Jurnal, Jurusan Teknik Permesinan Kapal, Program Studi Teknik Keselamatan dan Kesehatan Kerja, Politeknik Perkapalan Negeri Surabaya, 2019.

[15] Steven Boris, Total Productive Maintenance, New York; McGraw-Hill, 2006. 
Herman Budi Harja, Aditya Riyanto Putra, Wibawa Kresnandi

12 | JTRM 